\section{Effect of captopril on renal functional reserve in Type 1 (insulin-dependent) diabetes mellitus}

\section{Dear Sir}

There is good clinical evidence that measuring renal functional reserve, i.e., the capacity of the kidney to increase filtration in response to the stimulus of a protein meal or amino acid infusion, allows the estimation of the functional state of the glomeruli of the kidney [1-4]. In patients with Type 1 (insulin-dependent) diabetes mellitus in particular, impaired renal functional reserve indicates glomerular hyperfiltration $[1,4]$. Recently, long-term restriction of dietary protein from 1.0 to $0.6 \mathrm{~g} \cdot \mathrm{kg}^{-1} \cdot \mathrm{day}^{-1}$ was demonstrated as resulting in a significant increase in renal functional reserve in diabetic patients [2]. Two major questions follow from this observation: first, whether protein consumption in Type 1 diabetic patients with impaired renal functional reserve may be indeed increased in comparison to patients with normal renal functional reserve. Second, whether the effect of converting enzyme inhibition on renal functional reserve may be determined by the pre-existing state of glomerular function. We recently conducted a double-blind, randomized, placebo-controlled study [5] to examine the effect of captopril on renal haemodynamic response to amino acids in Type 1 diabetes. Twenty patients were enrolled (9 females, 11 males, age, $21-$ 50 years, haemoglobin $\mathrm{A}_{1}, 7.6-9.9 \%$ [normal, $<8.0 \%$ ], blood pres sure, $<140 / 90 \mathrm{~mm} \mathrm{Hg}$, urinary albumin excretion, $<20 \mu \mathrm{g} / \mathrm{min}$ ). $25 \mathrm{mg}$ captopril or placebo were given $90 \mathrm{~min}$ prior to the $2-\mathrm{h}$ infusion of $500 \mathrm{ml} 10 \%$ amino acid solution. For the present re-evaluation, patients were divided into two groups: In Group 1 (10 patients), renal functional reserve was normal (increase in inulin clearance in response to the amino acid infusion by $>+15 \%$ ) [4]. In Group 2 (10 patients), renal functional reserve was impaired. Patients in Group 2 differed from Group 1 in increased base-line inulin clearance (mean $\pm \mathrm{SEM}, 165 \pm 17$ vs $117 \pm 9 \mathrm{ml} \cdot \mathrm{min}^{-1} \cdot 1.73 \mathrm{~m}^{2-1}$, $p<0.05)$. Paraaminohippurate $(\mathrm{PAH})$ clearance was not significantly different $\left(602 \pm 61\right.$ vs $\left.516 \pm 43 \mathrm{ml} \cdot \mathrm{min}^{-1} \cdot 1.73 \mathrm{~m}^{2-1}\right)$. Moreover, patients in Group 2 differed from Group 1 in higher urinary urea excretion $(0.28 \pm 0.04$ vs $0.19 \pm 0.02 \mathrm{mmol} / \mathrm{min}, p<0.05)$, in increased base-line glucagon levels ( $98 \pm 10$ vs $63 \pm 8 \mathrm{ng} / \mathrm{l}, p<0.05$ ) and in slightly higher blood pressure $(130 \pm 4 / 86 \pm 3$ vs $119 \pm$ $5 / 81 \pm 3 \mathrm{~mm} \mathrm{Hg}, p<0.05$ for systolic blood pressure). There were no differences in haemoglobin $A_{1}$, nor in plasma levels of human growth hormone or human atrial natriuretic peptide. In the placebo study, the amino acid infusion increased inulin and $\mathrm{PAH}$ clearance in Group 1 by maximally $+38 \pm 12 \%$ and $+50 \pm 21 \%$, respectively (both $p<0.05$ ). In Group 2, there was a paradoxical decrease in both indexes by maximally $-20 \pm 8 \%$ and $-10 \pm 6 \%$, respectively (both $p<0.05$ vs Group 1). After captopril, inulin clearance in Group 1 was $128 \pm 14 \mathrm{ml} \cdot \mathrm{min}^{-1} \cdot 1.73 \mathrm{~m}^{2-1}$ and PAH rose to $742 \pm 97 \mathrm{ml} \cdot \min ^{-1} \cdot 1.73 \mathrm{~m}^{2-1} \quad(p<0.05$ vs placebo $)$. In Group 2, inulin clearance fell to $119 \pm 12 \mathrm{ml} \cdot \mathrm{min}^{-1} \cdot 1.73 \mathrm{~m}^{2-1}$ $\left(p<0.05\right.$ vs placebo) and PAH clearance was $810 \pm 140 \mathrm{ml} \cdot \mathrm{min}^{-1}$. $1.73 \mathrm{~m}^{2-1}$. After captopril, maximal rises in inulin and $\mathrm{PAH}$ clear- ance in response to the amino acid infusion were reduced in Group 1 to $+8 \pm 5 \%(p<0.05$ vs placebo $)$ and $+16 \pm 9 \%$, respectively. In contrast, captopril converted the responsiveness of both indexes in Group 2: inulin and PAH clearance rose by maximally $+21 \pm 15 \%$ $(p<0.05$ vs placebo) and $+22 \pm 17 \%$, respectively. Thus, the effect of converting enzyme inhibition on renal functional reserve in patients with Type 1 diabetes is indeed determined by the pre-existing state of glomerular function. In patients in Group 2 with glomerular hyperfiltration and impaired renal functional reserve, glomerular filtration was normalized by captopril administration and renal functional reserve greatly improved. In patients in Group 1 with normal renal functional reserve, it was as much blunted by captopril as previously observed in healthy subjects [4]. This diverging captopril effect emphasizes the role that angiotensin action on efferent glomerular vessels may play in the control of renal haemodynamic reactions. Although it is still a matter of considerable controversy whether all Type 1 diabetic patients with glomerular hyperfunction are at increased risk of eventually developing diabetic nephropathy [6], the effect of converting enzyme inhibition on renal haemodynamics in these patients may explain part of its beneficial action in patients with overt nephropathy [7]. On the other hand, the increased urinary urea excretion, a clinical indicator of increased protein consumption, which was observed in patients in Group 2 in comparison to Group 1 corroborates the probable usefulness of the recommendation [2] that diabetic patients with manifest signs of diabetic nephropathy should avoid long-term excess protein intake in addition to applying for near-normoglycaemic metabolic control, since both chronic hyperglycaemia and high protein consumption may indeed precipitate the progression of kidney disease by leading to impaired renal autoregulation. Increased glucagon levels may act as direct or at least indirect mediators of the effect of increased protein intake. However, neither human growth hormone nor, in particular, human atrial natriuretic peptide which both have been suspected previously of inducing glomerular hyperfunction [8] were proven to do so in our Type 1 diabetic patients.

Yours sincerely,

E.Jungmann and K.-H. Usadel

\section{References}

1. Nosadini R, Trevisan R, Fioretto P et al. (1989) Kidney hemodynamics after ketone body and amino acid infusion in normal and IDDM subjects. Diabetes 38: 75-83

2. Brouhard BH, LaGrone L (1990) Effect of dietary protein restriction on functional renal reserve in diabetic nephropathy. Am J Med 89:427-431

3. Bosch JP, Saccagi A, Lauer A, Ronco C, Belledonne M, Glabman $\mathrm{S}$ (1983) Renal functional reserve in humans. Effect of protein intake on glomerular filtration rate. Am J Med 75: 943-950

4. Eisenhauer T, Talartschik J, Scheler F (1986) Angiotensin converting enzyme inhibition by captopril reduces amino acid-medi- 
ated increase in glomerular filtration rate. J Hypertens [Suppl 5]: S258-S260

5. Eisenhauer T, Jungmann E, Warneboldt D, Ansorge G, Scherberich J, Talartschik J (1990) Verhalten der renalen Funktionsreserve von Typ I Diabetikern: Einfluß der Konversionshemmung. Klin Wochenschr 68: 750-757

6. Jones SL, Wiseman MJ, Viberti GC (1991) Glomerular hyperfiltration as a risk factor for diabetic nephropathy: five-year report of a prospective study. Diabetologia 34: 59-60

7. Zatz R, Dunn BR, Meyer TW, Anderson S, Rennke HG, Brenner BM (1986) Prevention of diabetic glomerulopathy by pharmacological amelioration of glomerular capillary hypertension. J Clin Invest 77: 1925-1930
8. Ortola FV, Ballermann BJ, Anderson S, Mendz RE, Brenner BM (1987) Elevated plasma atrial natriuretic peptide in rats: a potential mediator of hyperfiltration. J Clin Invest 80: 670-674

\section{Prof. Dr. E. Jungmann}

Department of Endocrinology

Center of Internal Medicine

Johann Wolfgang Goethe-University

Theodor-Stern-Kai 7

W-6000 Frankfurt am Main 71

FRG

\section{Diabetic retinopathy: preventing blindness in the 1990's}

\section{Dear Sir}

In the developed countries diabetic retinopathy is often not treated early enough, or is treated inadequately and sometimes not treated at all. Otherwise one could not explain why a complication for which effective treatment has been available now for over 10 years remains the most common cause of blindness in people between the ages of 30 and 64 years $[1,2]$. The main probiem is that patients with sight threatening lesions have to be identified; this is often difficult because the condition is asymptomatic at the stage when photocoagulation is most effective. In contrast, once vision is lost it is often difficult or impossible to restore it. Thus, we cannot wait for the patients to come to us, we have to plan prevention of blindness in diabetes mellitus through early detection of retinopathy, the obvious solution being screening. At present screening for diabetic retinopathy is haphazard, and not well organised. Screening programmes are expensive and time consuming, and health administrators in most countries have limited budgets which they find difficult to stretch to include the major work in organising preventive networks for eye care in diabetes.

The criteria for establishing screening services are: the condition must be an important health problem, affecting an identifiable population. An effective treatment must be available and, as well as a suitable screening test, acceptable to the population. The natural history of the condition must be understood, and an early pre-symptomatic stage must exist during which treatment is effective. Finally, the screening and treatment must be cost effective.

All these criteria are true for diabetic retinopathy. It has been shown to be an important health problem, and the population at risk, all diabetic patients, is easily identifiable. During the last 30 years the natural history of the condition has been clearly described, and in the 1970 's and early 1980's randomised controlled clinical trials have amply proved the value of photocoagulation [3-7]. In an analysis of previous papers Rohan et al. [8] noted an average reduction of blindness by $73 \%$ (range 61 to $85 \%$ ). The long-term effectiveness of treatment has also been shown $[9,10]$. Not only is blindness decreased, but the frequent occurrence of temporary visual loss due to recurrent vitreous haemorrhages is also reduced.

Is there a suitable screening test? Use of direct and indirect ophthalmoscopy through a dilated pupil will allow the identification of most patients who require treatment. Retinal photography using the non-mydriatic camera (though preferably with mydriasis), standard retinal photography preferably with stereo pictures of the macula, fluorescein angiography and slit lamp biomicroscopy all have their place in determining whom to treat, when to treat, and what to treat. When to use these methods and who should use them has long been a bone of contention. A recent workshop at the Hammersmith Hospital in London addressed these problems. The workshop was convened under the aegis of the European regions of the World Health Organisation (WHO) and the International Diabetes Federation, as a follow-up of the St. Vincent Declaration of 1989, which pledged to implement policies which will reduce the mortality and morbidity due to diabetes in Europe [11]. The workshop, at which ophthalmologists and diabetologists represented 21 European countries produced a consensus document on both screening and treatment [12].

There was uniform agreement about the importance of screening programmes. These have to be staffed by adequately trained personnel, who have direct access to treatment facilities. The diabetic patients have to be identified and persuaded to avail themselves of these screening procedures. All this requires time, organisation and also money. In order to convince the health authorities, with limited budgets that the investment in screening is cost effective we have to produce figures. Such figures are available from Scotland in 1983 [13], and from the USA, in 1989 [14]. Both these studies indicate that the financial expenditure involved in identifying and treating one patient at risk of blindness is approximately $1 / 10$ of the cost of maintaining this patient and his family on social benefit for the first year alone. This does not take into account the expenses of mobility training, teaching of Braille and re-training many of the sufferers. Nor does it take into account that blind patients and their families have to be supported for many years. Most important of all it does not take into account the improved quality of life maintaining vision confers.

The WHO will distribute the documents produced to the various European governments. The diabetologists and the ophthalmologists are already aware of the importance of screening. Thus, double pressure, from above and below, should force health authorities to support screening programmes. But organisation of these, implementation of the aims of the St. Vincent Declaration [11] to reduce the incidence of new blindness by one third in the next 5 years, remains in the hands of the doctors. Hopefully we are ready for this huge but important task.

Yours sincerely,

E. M. Kohner and M. Porta

\section{References}

1. Sorsby A (1972) The incidence and causes of blindness in England and Wales 1963-1968. 68. Reports on Public Health and Medical Subjects 128: 20-33

2. Herman WH, Teutsch SM, Sepo SJ (1983) An approach to the prevention of blindness in diabetes. Diab Care 6: 608-613

3. British Multicentre Study Group (1984) Photocoagulation for proliferative diabetic retinopathy: a randomised controlled clinical trial using the xenon arc. Diabetologia 26: 109-115

4. Diabetic Retinopathy Study Research Group (1981) Photocoagulation treatment of proliferative diabetic retinopathy. Ophthalmology 88: 583-600

5. British Multicentre Study Group (1983) Photocoagulation for diabetic maculopathy: a randomised controlled clinical trial using the xenon arc. Diabetes 32: 1010-1016 